\title{
ROLE OF JUDICIARY FOR PROTECTION OF ENVIRONMENT IN INDIA
}

\author{
Dr. Pratap Chandra Dash \\ Principal, Barpeta Law College \\ Barpeta-781301, \\ Assam.
}

Article DOI: $\underline{\text { https://doi.org/10.36713/epra6627 }}$

\begin{abstract}
The problem of environmental pollution is not new in its origin. However, different dimensions of the problem of environment protection and its management have taken a serious turn in the present era. Today, the role of judiciary depends on the nature of political system adopted by a particular country. In view of legislative and executive in differences of failures but the role of judiciary has been critical in shaping the environmental laws and policies.
\end{abstract}

KEY-WORDS: Environment, Protection, Judiciary, Policy and Role.

\section{INTRODUCTION}

Environment, being an inter-related discipline, policies and laws are needed to safe guard and protect natural environment. The Government of India has taken systematic and sustained efforts to tackle major environmental problems of this country. One of the efforts is to formulate comprehensive 'Policy frame work" to enable the government to have a holistic view of all environmental issues and to formulate "Environmental Plan" for the country.

There are several policy statements relating to environment namely Industrial Policy Statement (1980), National Land use Policy (1986), National Water Policy (1987), National Land use Policy (1988), National Forest Policy (1988), Policy Statement for abetment of pollution (1992), The National Conservation Strategy and the Policy Statement on Environment and Development (1992), Ocean Policy Statement, National Agriculture Policy (2000), Wild Life Conservation Strategy (2002) and The Environment Policy Statement (2006). National Environment Policy, 2006 is more specific in recognizing the polluter pays principle in order to achieve economic efficiency in environmental conservation. This Principle requires that the services of environmental resources be given economic value, and such value to count equally with the economic values of other goods and services, in analysis of alternative courses of action.

The formulation of above policy statements has fulfilled a long standing demand of devising a clear and precise national policy on environmental protection and management. A few of the policy directives have been formulated into legislations. The main legislations on environmental protection are: The Indian Fisheries Act, 1897; The Indian Forest Act, 1927; The River Boards Act, 1956; The Water (Prevention and Control of Pollution) Act, 1974; The Water Cess (Prevention and Control of Pollution) Act, 1977; The Environment (Protection) Act, 1986; The Mines and Minerals (Regulation and Development) Act, 1957; The Atomic Energy Act, 1962; The Air (Prevention and Control of Pollution) Act, 1981; The Environment (Protection) Act, 1986; The Public Liability Insurance Act, 1991 and The Environment Tribunal Act, 1995.

Apart from statutes, the remedy for environmental harm is available in law of tort under the categories of negligence nuisance, trespass and strict liability. 


\section{ROLE OF INDIAN JUDICIARY}

The role of judiciary depends on the very nature of political system adopted by a particular country. This is the reason that role of judiciary varies in liberal democracy, communist system and countries having dictatorship. The role of judiciary has been important in liberal democracies like India. The Constitution of India in fact took inspiration from US Constitution and therefore adopted similar concept of judicial review. In independent India, history of judiciary, judicial review and judicial activism has been a fertile area for legal researchers. It is now a well established fact that, in India, in view of legislative and executive indifferences or failures, the role of judiciary has been crucial in shaping the environmental laws and policies. The role of the Indian Supreme Court may be explained quoting the views of Professor S.P. Sathe and Professor Upendra Baxi two leading academics who have extensively written on the role of judiciary in India. Professor Sathe has analyzed the transformation of the Indian Supreme Court "from a positivist court into an activist court". Professor Upendra Baxi, who has often supported the judicial activism in India, has also said that the "Supreme Court of India" has often become "Supreme Court for Indians". ${ }^{1}$ Many observers of the Indian Supreme Court including Professor Sathe and Baxi have rightly opined that the Indian Supreme Court is one of the strongest courts of the world. ${ }^{2}$

Power and judicial activism of the Indian courts have resulted into a strong and ever expanding regime of fundamental rights. Stockholm Conference on Human Environment, 1972, has generated a strong global international awareness and in India it facilitated the enactment of the $42^{\text {nd }}$ Constitutional Amendment, 1976. This amendment has introduced certain environmental duties both on the part of the citizens [Article 51A (g)] and on the state (Article 48-A).

Under the constitutional scheme the legal status of Article 51(A)-(g) and 48-A is enabling in nature and not legally binding per se, however, such provisions have often been interpreted by the Indian courts as legally binding. Moreover, these provisions have been used by the courts to justify and develop a

1 Upendra Baxi, 'The Avatars of Indian Judicial Activitism : Explorations in the Geography of (In) justice', in S.K. Verma and Kusum (eds.), Fifty Years of the Supreme Court of India : It's Grasp and Reach (Delhi, Oxford University Press, 2000) pp. 156-209 at 157.

2 S.P. Sathe, Judicial Activism in India (New Delhi, Oxford University Press, 2000). See, 'Preface' of this work written by Prof. Upendra Baxi, pp. ixxxi. legally binding fundamental right to environment as part of right to life under Article $21 .{ }^{3}$ Hereinafter, an effort has been made to demonstrate that how both the 'soft' and 'hard' international environmental laws have been used by the Indian courts to develop a strong environmental jurisprudence in domestic law.

The higher Judiciary in its new role played a crucial role in protecting the environment through public interest litigation covering various aspects of environmental degradation under Article 32 and Article 226 of The Constitution of India, 1950.

The Supreme Court of India formulated the doctrine of absolute liability for harm caused by hazardous and inherently dangerous industry by interpreting the scope of the power Under Article 32 of the Constitution of India in a PIL. ${ }^{4}$ Regarding the liability of an enterprise which is engaged in an hazardous or inherently dangerous industry, the Court observed: "We are of the view that an enterprise which is engaged in a hazardous or inherently dangerous industry which poses a potential threat to the health and safety of the persons working in the factory and residing in the surrounding areas owes an absolute and non delegable duty to the community to ensure that no harm results to any one on account of hazardous or inherently dangerous nature of the activity which it has undertaken. It further observed-that the enterprise must be held to be under an obligation to provide that the hazardous or inherently dangerous activity in which it is engaged must be conducted with the highest standard of safety and if any harm results on account of such activity, the enterprise must be absolutely liable to compensate for such harm and it should be no answer to the enterprise to say that it had taken all reasonable care and that the harm occurred without any negligence on its part". ${ }^{5}$ On the question of the measure of the compensation, the court pointed out that it must be correlated to the magnitude and capacity of the

$3 \quad$ R.L.E.K., Dehradun v. State of U.P. (Doon Valley Matter) was the first case in which the Supreme Court recognized a fundamental" right to live in a healthy environment with minimum disturbance of ecological balance". A.I.R. 1985 SC 625 at 656.

4. Supreme Court On The Doctrine Of Absolute Liability And Polluter Pay's Principle:An Analysis by Manjunatha $\mathrm{N} \mathrm{G1}$; International Journal Of Research And Analysis, 2014, Volume 2 Issue 3.

${ }^{5}$. M.C. Mehta v. Union of India, 1987 AIR $1086: 1987$ SCR (1) 819. 
enterprise because such compensation must have a deterrent effect. ${ }^{6}$

Internationally recognized concept of Sustainable Development means a development that meets the needs of the present without compromising the ability of future generations to meet their own needs. The definition meets enough scepticism due to unclarity of idea that it express. Taking into consideration the Brundtland Report and international documents like Rio Declaration 1992 and Agenda-21, the salient features of the concept may be summarised to comprise as: Intel-generational equity, Use and conservation of natural resources for environmental protection, Precautionary principle, Obligation to assist and cooperate, Eradication of Poverty, Financial assistance to the developing countries and The Polluter pays principle. ${ }^{7}$

The Apex court of India has recognized that the precautionary principle and polluter pays principle are part of the Environmental law of the country. ${ }^{8}$

\section{Precautionary Principle}

The precautionary Principle essentially speaks of taking of such measures by which environment can be protected from the activities that degrade the environment and as well from such other activities which are yet not scientifically established to be harmful to the environment.

The main purpose of the precautionary Principle is to ensure that a substance or activity posing a threat to the environment is prevented from adversely affecting the environment, even in case there is no conclusive scientific proof of linking that particular substance or activity to environmental damage, this principle has been accepted and adopted by several international documents. ${ }^{9}$

Polluter Pays Principle

6. Supreme Court On The Doctrine Of Absolute Liability And Polluter Pay's Principle: An Analysis by Manjunatha N G1; International Journal Of Research And Analysis, 2014, Volume 2 Issue 3.

7. Our Common Future, Chapter 2: Towards Sustainable Development, From A/42/427. Our Common Future: Report of the World Commission on Environment and Development.

8 . Vellore Citizens' Welfare Forum v. Union of India, (1996) 5 SCC 647 (Page 658, Para 11) : AIR 1996 SC 2715.

9 Precautionary Principle Of Environmental Law; https://newindialaw.blogspot.in/2013/05/

precautionary-principle-of.html
The first major reference to the polluter pays principle appeared 1972 in the Organization for Economic Co-operation and Development Guiding Principles concerning international economic aspects of environmental policies. The PPP as a guiding principle across countries became necessary because some countries faced complaints by national firms about rising costs and a loss of international competitiveness following a national implementation of the PPP with in the their borders. ${ }^{10}$

The OECD guiding principles defines the PPP as an instrument for "....... Allocating costs of pollution, prevention and control measures", the polluter should bear these costs in order to achieve and maintain an acceptable state of environment, "which is determined by the public authorities. ${ }^{11}$

\section{Judicial adoption of international environmental law into domestic law in India}

The judicial adoption of international environmental law into domestic law in India has not been done overnight rather it has been gradual.

During the period of 1950 to 1984 the Indian courts have adopted a traditional dualist approach that treaties have no effect unless specifically incorporated into domestic law by legislation. In Jolly George Verghese v. Bank of Cochin ${ }^{12}$ the Supreme Court upheld the traditional dualist approach and gave overriding effect to the Civil Procedure Code over International Covenant on Civil and Political Rights. However, the court in this case, minimizes the conflict between the Covenant and domestic statue by narrowly interpreting the Civil Procedure Code.

As far as the customary international law is concerned, during 1950-84, there was hardly any legislative exercise in the name of customary international law.

The Indian judicial approach relating to the legal status of the customary international law was clarified in Gramophone Company of India Ltd. v. Birendra Bahadur Pandey. ${ }^{13}$ In this case the court relied upon the English decisions and endorsed the doctrine of incorporation. According to this doctrine rules of international law are incorporated into national law and considered to be part of national law unless they are in conflict with an Act of the parliament.

10 Concept of Polluter Pay Principle (PPP) , https://www.researchgate.net/

11 Polluter Pays Principle Has Become a Popular Catchphrase, https://www.scribd.com

12 (1980) 2 SCJ 358.

13 (1984) 2 SCC 534. 
During 1985-1995 international environmental law was used to interpret the character of state obligations with respect to the right to life (Article-21), which has been interpreted to include the right to a healthy and decent environment.

Before 1996 there were very few references to international environmental treaties though by 1990 India was party to more than 70 multilateral treaties of environment significance. ${ }^{14}$

In Asbestos Industries Case ${ }^{15}$ the Supreme Court extensively quoted many international laws namely ILO Asbestos Convention, 1986, Universal Declaration of Human Rights, 1948, and International Convention of Economic, Social and Cultural Rights, 1966. In this case the court dealt the issues relating to occupational health hazards of the workers working in asbestos industries. The court held that right to the health of such workers is a fundamental right under article 21 and issued detailed directions to the authorities. ${ }^{16}$ In Calcutta Wetland Case ${ }^{17}$ the Calcutta High Court stated that India being party to the Ramsar Convention on Wetland, 1971, is bound to promote conservation of wetlands. ${ }^{18}$

The Stockholm Declaration, 1972 and the Rio Declaration, 1992 have been considered milestones in the development of international environmental law. Though these two declarations have often been characterized as 'soft' law but their impacts both at international and domestic levels, have been profound. In India, the post Bhopal Gas Disaster era (after 1984) was a creative period for environmental jurisprudence. During this period, in landmark Doon Valley case ${ }^{19}$, the Supreme Court dealt with the impact of mining in the Doon Valley region and through its orders impliedly generated a new fundamental "right of the people to live in healthy environment with minimal disturbance of ecological balance." 20 In this case there were series of orders and in one of its orders the court recognized the influence of the Stockholm Conference by

14 Anderson, (1998), op. cit., note13, p. 26.

15 Consumer Education \& Research Centre v. Union of India, 1995 AIR 922: (1995) 3 SCC 42.

16 Principles Of International Environmental Law And Legal Status In India; Journal of Global Resources, January 2016, Vol 2., pp. 103-108.

17 People United for Better Living in Calcutta v. State of W.B., AIR 1993 Cal. 215.

18 Principles Of International Environmental Law And Legal Status In India; Journal of Global Resources, January 2016, Vol. 2., pp. 103-108.

19 R.L.E.K. Dehradum, v. State of U.P. AIR 1985 SC 652. Three judges bench order of March 12, 1985

20 Ibid, 656 (Para 12). accepting that this "conference and the follow-up action thereafter is spreading the awareness". ${ }^{21}$ Again, in Kanpur Tanneries Case 22 the Supreme Court extensively quoted the Stockholm Declarations and strengthened the then nascent fundamental right to environment in India. In this case the court gave preference to 'environment' over 'employment' and 'revenue generation'. During this period the Rio Declarations, 1992 was also cited in the Law Society of India case. ${ }^{23}$

During this period of $1985-1995$, according to Prof. Anderson, the said soft laws were invoked by the court simply to make the general point that environment should be protected. The use and role of soft laws was 'secondary' rather than 'substantive'. ${ }^{24}$ The courts were just using soft law standards to evolve and strengthening the fundamental right jurisprudence under Article 21. In fact, international environmental law played primary and substantive role in the next period starting from the year 1996.

In contrast to its previous caution during 19851995 periods, the Supreme Court adopted a more robust attitude to customary international law in the year $1996 .{ }^{25}$ In the year 1996 the Supreme Court, led by an activist green judge- Justice Kuldip Singh, inaugurated a new environmental jurisprudence in historic Vellore case ${ }^{26}$ and invariably applied the ratio of this case in a series of other landmark environmental cases. In all such cases international environmental law was used 'substantively' and the Supreme Court developed a unique domestic environmental jurisprudence by blending the Indian environmental law with the international environmental law. Hereinafter, an effort has been made to discuss important cases of this period and their outcome.

In Vellore case the court considered a public interest litigation highlighting discharge of toxic waste and polluted water from the large number of tanneries

21 AIR 1987 SC 359, 363 (Para 19) order of Dec. 18, 1986.

22 M.C. Mehta, v. Union of India AIR 1988 SC 1037. See Para 4 (pp. 1038-1040) for detailed discussion of Stockholm Declarations by Justice Venkataramiah.

23. Law Society of India v. Fertilizer \& Chemical Travancore Ltd. AIR 1994 Ker. 308.

24 Anderson, (1998), op. cit., note13, p. 25.

25 Ibid.

26 Vellore Citizens' Welfare Forum v. Union of India (1996) 5 SCC 647 : AIR 1996 SC 2715 Unanimous Judgment delivered on August 28, 1996; by a three judges bench of the Supreme Court of India. 
in the State of Tamil Nadu. A three judges' bench led by Justice Kuldip Singh adopted a very strict stand against the polluting tanneries. In this case the court reviewed the history of the concept of sustainable development under international law. In this connection the court briefly referred important legal developments such as the Stockholm Conference 1972, Burndtland Commission Report, 1987, Caring of the Earth Report, 1991, Rio Conference, 1992, Convention on Climate Change, 1992, Convention on Biological Diversity, 1992 and Agenda -21 (A programme of Action for Twenty-first Century) etc. The important legal findings of the Vellore case, relevant for this research study, are summarized below.

- The court held that "Sustainable Development" as a balancing concept between ecology and development has been accepted as a part of customary international law though its salient features are yet to be finalized by the international law jurists.[(1996) 5 SCC 647, Para 10].

- The court was of the view that "The Precautionary Principle" and "The Polluter Pays Principle" is essential features of "Sustainable Development." (ibid., p. 658, Para 11).

- The Precautionary Principle and the Polluter Pays Principle have been accepted as part of the law of the land. (ibid., pp. 659-660, Paras $13 \& 14)$.

- According to the court, "once these principles are accepted as part of the customary International law there would be no difficulty in accepting them as part of the domestic law. It is almost an accepted proposition of law that the rules of Customary International Law which are not contrary to the municipal law shall be deemed to have been incorporated in the domestic law and shall be followed by the courts of law". ${ }^{27}$ (ibid. 660, Para 15).

\section{Vellore Case in Development of Environmental Law in India}

Vellore case has been proved a turning point of the growth of environmental law in India. Though the

27 In support of this conclusion the court referred to Justice H.R. Khann's opinion in the A.D.M. Jabalpur v. Shivakant Shukla (1976) 2 SCC 521: AIR 1976 SC 1207, Jolly George Varghese v. Bank of Cochin, (1980) 2 SCC 360 : AIR 1980 SC 470 and Gramophone Co. of India Ltd. v. Birendra Bahadur Pandey, (1984) 2 SCC 534 : AIR 1984 SC 667. aforementioned outcome/ratio of the Vellore case has often been questioned by the critics $^{28}$ but the Supreme Court it has never cast a doubt on the ratio of this case. Conversely the courts in India have been enthusiastically applying the ratio of the Vellore case in majority of environmental cases. Hereinafter, an effort has been made to present an account of those cases in which Vellore case has been cited, approved and used. This discussion can be divided into two broader heads as below.

The Supreme Court led by Justice Kuldip Singh decided the Vellore case on August 28, 1996, and in several important subsequent judgments written by him ${ }^{29}$ he applied the ratio of the Vellore case. This account has been presented in a tabular form as below.

28 For example Prof. B.C. Nirmal, an expert of international law at Law School, BHU, has questioned the reasoning of the Vellore case. See, B.C. Nirmal, 'From Vellore to Nayudu : The Customary Law Status of the Precautionary Principle; 30 Banaras Law Journal (2001) 58-99. For criticism of Vellore's ratio, See also, Anderson, (1998), op. cit; note 13, pp. 27-28. In his concluding observations Prof. Anderson opines that "The direct incorporation of international environmental law principles raises serious questions regarding both the content of domestic environmental law and the place of international law in India's constitutional order. It would not be surprising if these matters are raised by industry groups in future litigation." (ibid.,p 28). For example, in Bhopal Mass Disaster litigation the Union Carbide Corporation seriously contested the ratio of absolute liability principle of the Oleum Gas Leak case (AIR 1987 SC 1086). In Vellore case Justice Kuldip Singh affirmed the mixing of the Polluter Pays Principle with the Absolute Liability Principle (Para 12 at pp. 658-59 in SCC Report). Prof. Anderson opines that such mixing has no support under the international environmental law which has been invoked by the court to from the ratio of the Vellore case.

${ }^{29}$ Except one order written by Justice Hansaria to which Justice Kuldip Singh was the party. See serial number 1 in the table. 
Table this exercise Vellore case was virtually converted as the

\begin{tabular}{|c|c|c|c|}
\hline S.No. & $\begin{array}{c}\text { Cases in Which Vellore Case } \\
\text { Applied }\end{array}$ & $\begin{array}{c}\text { Date of Order/ } \\
\text { Judgment }\end{array}$ & $\begin{array}{c}\text { Judge Who Delivered the } \\
\text { Order/ Judgment }\end{array}$ \\
\hline 1. & Bayer India Ltd. case ${ }^{30}$ & Sept. 09, 1996. & $\begin{array}{c}\text { Justice B.L. Hansaria, (Justice } \\
\text { Kuldip Singh was a member of the } \\
\text { Bench) }\end{array}$ \\
\hline 2. & $\begin{array}{c}\text { Badkal \& Surajkund Lakes } \\
\text { case }^{31}\end{array}$ & Oct. 11, 1996. & Justice Kuldip Singh \\
\hline 3. & $\begin{array}{c}\text { Suo Motu case (Vehicular } \\
\text { Pollution in Delhi matter) }^{32}\end{array}$ & Nov. 18, 1996 & Justice Kuldip Singh \\
\hline 4. & Shrimp Culture case 33 & Dec. 11, 1996 & Justice Kuldip Singh \\
\hline 5. & Kamal Nath case $^{34}$ & Dec. $13,1996$. & Justice Kuldip Singh \\
\hline 6. & Calcutta Tannaries case ${ }^{35}$ & Dec. 19,1996 & Justice Kuldip Singh \\
\hline 7. & Taj Trapezium case 36 & Dec 301996. & Justice Kuldip Singh \\
\hline
\end{tabular}

Analysis of the above cases shows that within a short period of four months i.e. from Sept. 1996 to Dec. 1996, the ratio of Vellore case was applied in seven important cases by the Supreme Court. Out of these seven cases, six judgments have been written/ delivered by Justice Kuldip Singh himself and there was no dissenting opinion by the other judges in such cases. Only in one case namely Bayer India Ltd, the judgment was delivered by Justice Hansaria on behalf of a division bench of which Justice Kuldip Singh was also a member. In these seven cases ratio of the Vellore case $^{37}$ was verbatim referred and approved. Through

$30 \quad$ F.B. Taraporwala v. Bayer India Ltd. (1996) 6 SCC 58, 61 (Para 4).

31 M.C. Mehta (Badkal and Surajkund Lakes Matter v. Union of India (1997) 3 SCC 715, 718-20. (Para $8 \& 10)$.

32 Suo Motu Proceeding In Re : Delhi Transport Development (1998) 9 SCC 250; 251. Justice Kuldip Singh (Joint order of the Div. bench) applied the precautionary principle as part of sustainable development to establish a legal duty of the state government to control the vehicular pollution in Delhi).

33 S Jagannath, v. Union of India (1997) 2 SCC 87, 143-46 (Para 47).

34 M.C. Mehta v. Kamal Nath (1997) 1 SCC 388, 413-414 (para 37 \& 38).

35 M.C. Mehta (Calcutta Tannaries' Matter) v. Union of India (1997) 2 SCC 411, 429-430 (Para 18 \& 19).

36 M.C. Mehta (Taj Trapezium Matter) v. Union of India (1997) 2 SCC 353, 382-83. (Para 32).

37 It is a matter of surprise that during the year 1996 itself Justice Kuldip Singh court delivered many orders/judgments prior to the Vellore case (Aug.28, 1996), but, in none of these cases he invoked the international law principles to decide ground norm by Justice Kuldip Singh without stating that it was he who created this ground norm. The fact, that out of seven, six judgments delivered / written by Justice Kuldip Singh he suggests that before his retirement, which was due in Dec. 1996, he wanted to establish the ratio of Vellore as a settled precedent under Indian environmental jurisprudence.

Even after retirement of Justice Kuldip Singh in Dec. 1996 the entire ratio of Vellore case remained intact. In fact, this ratio of Vellore has been further strengthened when in many other important environmental cases the Supreme Court reiterated and upheld the same. But, in post Kuldip Singh era nature and extent of the application of Vellore's ratio has varied from case to case. In these cases, briefly

the said cases as he did in the Vellore case. These cases are : Delhi Water Supply case, Feb. 29, 1996. (1996) 2 SCC 572; Dr. B.L. Wadehra case March 01, 1996, (1996) 2 SCC 594; Coastal Regulation Zones case April 18, 1996 : (1996) 5 SCC 281; Badkal and Surajkund Lakes case (main order) May 10, 1996 : (1996) 8 SCC 462. In M.C. Mehta v. Union of India (Delhi Hazardous Industries Relocation Matter) Justice Kuldip Singh court delivered two orders on May 10, 1996 (1996) 4 SCC 351 and July 08, 1996, (1996) 4 SCC 750 and no reference to the Vellor case was made. It may be pointed out here that in the main order (May 10, 1996) in Badkal Lake Case there was no use of international environmental law principle but in the clarificatory order (Oct. 11, 1996) of the same matter Justice Kuldip Singh court extensively used the international environmental law principles by reiterating the ratio of the Vellore case. The present author has not succeeded to find explanation of this sudden departure of judicial attitude of Justice Kuldip Singh court within the short span of few months. 
mentioned below, the courts have made passing references or restrictive use or selective use of Vellore's ratio. However, there has been no dissent against the Vellore's ratio in these cases.

In Samatha case 38 only meaning and importance of the term sustainable development as well as "the polluter pays principle as a facet thereof" have been briefly mentioned and affirmed by the Supreme Court. In Nuyudu case ${ }^{39}$ citing Vellore case the Supreme Court felt it necessary to further elaborate the meaning of precautionary principle in more detail'. (Para. 32, p. 733).

In Sardar Sarovar Dam ${ }^{40}$ majority judgment (Kirpal, J. for himself and Anand, CJI.) referred the Nayudu \& Vellore Cases and approved the construction of a mega dam and found it compatible with the concept of sustainable development which requires that mitigate steps should be taken. The court refused to apply the precautionary principle in this matter by distinguishing the dam with the hazardous industries.

The first recognition of the principle (PPP) by judiciary can be seen from the judgment delivered by the Supreme Court of India in writ petition no. 657 of 1995. In it orders dated Feb - 4, 2005. The Supreme Court held that "The PPP means that absolute liability of harm to the environment extends not only to compensate the victims of pollution, but also to the cost,of restoring environmental degradation. Remediation of damaged environment is a part of the process of sustainable development.

The Supreme Court for the first time applied the polluter pays principle explicitly in "Indian Council for Enviro-Legal Action v. Union of India ${ }^{41}$ in which the Court held that the polluting industries are absolutely liable to compensate for the harm caused by them to the villagers in the affected area, to the soil and to the underground water and hence they are bound to take all necessary measures to remove sludge and other pollutants lying in the affected areas. The Supreme Court further directed the Central Government to determine the amount required for carrying out the remedial cost of the environment in consultations with appropriate ministry, utilizing its power under Section

38 Samatha, v. State of A.P. \& others (1997) 8 SCC 191, 274. (Para 123) (Decided on July 11, 1997 by three judges' bench).

39 A.P. Pollution Control Board v. Prof. M.V. Nayudu (1999) 2 SCC 718, 732-34 (Para 30, 31 \& 36).

40 Narmada Bachao Andolan v. Union of India 2000 (7) SCALE 34, 91-92. (pares 119-121) (AIR 2000 SC 3751).

41. AIR 1996 SC 1446.
3 and Section 5 of the Environment (Protection) Act of 1986.

In The Vellore Citizens Welfare Forum v. Union of India ${ }^{42}$, the Supreme Court declare that the Polluter Pays Principle has been held to be a sound principle and directed the Central Government to constitute an authority under Section 3(3) of the Environment (Protection) Act, 1986 with the power to compute the compensation applying polluter pays principle under two heads namely for reversing the ecology and for payment to individual victims. It further ordered imposition of pollution fine of Rs. 10,000/- from each of the polluting tenancy Industries. The fine so recovered from polluter had to be deposited under a separate head Environment Protection Fund. The Supreme Court ordered creation of Environment Protection fund in this case and directed the fund to be utilized for compensating the affected persons as identified by authorities and also for restoring the damaged environment.

The Supreme Court of India in M.C.Mehta v. Union of India ${ }^{3}$, has impliedly applied the polluter pays principle to deal with the problem caused by the oleum gas leakage from the Shriram Food and Fertilizer Corporation.

The Supreme Court reiterated the "PPP" and reemphasized the need to apply it in "MC Merita v. Union of India. ${ }^{43}$ It was a case concerning the "yellowing and decaying of the Taj Mahal". The Apex court ordered industries either to change the energy pattern or to relocate or close. It further ordered compensation for the harm caused and a mechanism to be developed for the same.

The Supreme Court applied the PPP in another land mark decision in the case of " $S$. Jaganath vrs Union of India. ${ }^{44}$ In this case, it was found that the Shrimp Culture industry in and around Chilka and Pulikat lakes adjacent to the east coast was causing salinity of the-soil and the drinking water. This Industry also caused detrimental effects on the local Flora and Fauna.

The Supreme Court has also applied the "PPP" in M.C. Mehta v. Kamalnath. ${ }^{45}$ In this case the Supreme Court held that the Span Motel interfered into the natural flow of the river Beas by trying to block the natural flow of the river. Hence, the motel was directed to pay compensation by way of cost for the restitution

\footnotetext{
42. AIR 1996 SC 2715

43. AIR 1997 SC 734

44. AIR 1997 SC 811.

45. AIR 2000 SC 1997.
} 
of the environment and ecology of the area by applying the above principle.

In Karnataka industrial Area Development Board v. C. Kenchappa ${ }^{46}$ the Apex Court observed. "The polluter pays principles demands that the financial costs of preventing or remedying damage caused by pollution should lie with the undertakings which cause the pollution or produce the goods which cause the pollution. Under the principle, it is not the role of Government to meet the costs involved in the prevention of such damage or in carrying out remedial action, because the effect of this would be to shift the financial burden of the pollution incident to the taxpayers."

In Deepak Nitrate Ltd. v. State of Gujarat ${ }^{47}$ the Supreme Court supported the proposition that the measure of compensation must be co-related to the magnitude and capacity of the enterprise because such compensation must have a deterrent effect and such damage not only extends to restitution for the harm to the environment, to compensate the victims of the pollution but also cost of restoring the environment from degradation. This court reiterated the principle of "Polluter to pay" to the effect that one of the principles is to levy damages of a certain percentage of total turnover and the right to a clean and hazardless environment has been recognized as a fundamental right under Art. 21 of the Constitution. The court has innovated new methods and strategies for the purpose of securing enforcement of fundamental rights.

\section{CONCLUSION AND SUGGESTIONS}

The judiciary has made efforts in preserving India's natural environment by insisting upon implementation of the laws and where the laws were found insufficient to deal with a particular situation, leading concepts; such as sustainable development, precautionary principal, and polluter pay principles etc. into Indian law achieve this end.

The development of polluter pays principle has been mainly due to the efforts of the supreme court of India. The High Courts have also rendered many important decisions but only these have not really had any visible or major impact on polluter pays principle. To a large extent, the Indian judiciary has been pressed to undertake such an active role due to the inefficiency of the current environmental regime, even though the statutes and legislation are well defined and stringent, their implementation and enforcement have not been efficient.

$\begin{array}{ll}{ }^{46} . & \text { AIR } 2006 \text { SC } 2038 . \\ { }^{\circ} . & \text { AIR } 2004 \text { SC } 3407 .\end{array}$ 